CURRENT RESEARCH JOURNAL OF PHILOLOGICAL SCIENCES

(ISSN -2767-3758)

VOLUME 03 ISSUE 01 Pages: 73-78

SJIF IMPACT FACTOR (2021: 5. 823)

OCLC - 1242423883 METADATA IF - 6.925

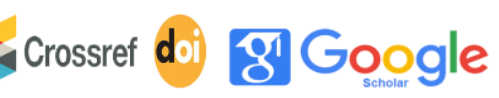

\%

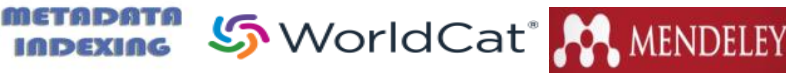

Publisher: Master Journals

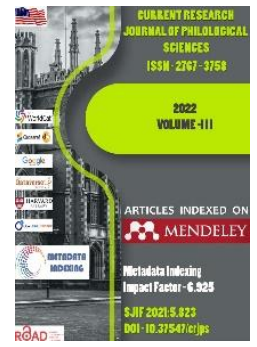

Journal Website: https://masterjournals. com/index.php/crips

Copyright: Original content from this work may be used under the terms of the creative commons attributes 4.0 licence.
Research Article

\section{ACTIVE USE OF PURE UZBEK WORDS AND APPENDIXES IN THE COMIC WORKS OF ABDULLA QADIRI}

\author{
Submission Date: January 11, 2022, Accepted Date: January 21, 2022, \\ Published Date: January 31, 2022 \\ Crossref doi: https://doi.org/10.37547/philological-crjps-03-01-11
}

Madikhabonu Kh. Pardayeva

Senior Lecturer Navoi State Pedagogical Institute Navoi, Uzbekistan

\title{
ABSTRACT
}

It is analyzed that Abdullah Qadiri used Uzbek words and suffixes that not available in Uzbek dictionary contents, but can be actively used today, especially, in his comic works Uzbek words are more than others and also some examples that in order to reveal the character of the roles he also used indirect speech when is necessary.

\section{KEYWORDS}

Metaphor, metonemia, linguistic portrait, humorous spirit, lexeme, sema, morpheme.

\section{INTRODUCTION}

Abdulla Qadiri is also a major contributor to the development of Uzbek journalism. The linguistic units used in the text of novels and comics are, of course, somewhat different. From the synonymous range of words, other words are chosen for the novel, other words for comics, and more negatively colored words are used. Phrases also have a sense of humor. This is the lexical feature of comic works, the morphological features of such texts have not been studied in depth, the morphemics, morphology of the Uzbek language, the specific meaning of auxiliary word groups in the comic text have not been studied as a separate object of study. Abdulla Qadiri is an artist who has made a significant contribution not only to the development of Uzbek literary style and journalism, but also to the development of Uzbek grammar. In this context, the 


\section{CURRENT RESEARCH JOURNAL OF PHILOLOGICAL SCIENCES}

(ISSN -2767-3758)

VOLUME 03 ISSUE 01 Pages: 73-78

SJIF IMPACT FACTOR (2021: 5. 823)

OCLC - 1242423883 METADATA IF - 6.925

\section{Crossref

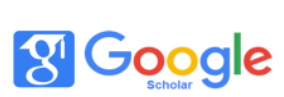

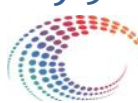

metapata

5. WorldCat ${ }^{*}$ भ̂े MENDELEY

Publisher: Master Journals

lexical and morphological study of the language of his comics is a very important topic.

\section{THE MAIN RESULTS AND FINDINGS}

Qadiri's comic book, "Tinch ish", contains a number of emotionally charged linguistic devices. [Endi bu zot ham ulamodan biri edi. O'z ilmi tarafidan varasatulanbiyo qatorig'a kiritilgan uchun mertuqsertuqlarning falon-tuganiga quloq soluvning ham luzumi yo'q edi. Yigirma besh-o'ttuz yilni madrasa tuprog'i yalab o'tkargan bir kishini, tabi'iy, bizda ulamo qatorig'a kirguzmay hol yo'q]. In this example, the phrase "madrasa tuprog'i yalab" is used by the author appropriately and purposefully. This phrase can be used differently depending on the context of the speech. It was used to draw a more accurate linguistic portrait of the teacher, and began to add humor to the story. The repetition of this phrase two or three times also served to increase its effectiveness: [Ham ana shu madrasa tuprog'ini o'ttuz yil yalab shul tuproq yalov ajrini ham olg'an edi].

In terms of the content of the lexemes, in addition to naming the reality, the attitude to the named reality is also expressed. The sign of reaction to reality is called the evaluation semaphore. For example, the lexemes qush- and qushcha- are the same in terms of lexical meaning and different in terms of value. Qush lexeme is neutral in terms of evaluation semantics: it does not express a positive or negative attitude to what is being expressed; qushcha - lexeme expresses such an attitude. Thus, the semantic content of the lexeme қушча is the main phenomenon in terms of the content of the lexeme - lexical meaning; assessment semaphore surrounds lexical meaning. The rating semaphore is basically represented in three ways:

1) using a morpheme,

2) with the lexeme itself,

\section{3) using context.}

Expressing the value semaphore using a morpheme is called morphological expression. In modern Uzbek, the morphemes -cha (like qushcha-), -gina (like qizginam), -jon (like otajonim), -chak, -chiq (like kelinchak-, qo'zichoq-) perform such a function. These morphemes are called lexical expressions if they are expressed by the lexeme itself. In this case, the semantics of evaluation is evident in the semantic relationship between the lexemes. For example, the lexemes yuz-, bet-, aft-, bashara - have the same lexical meaning, but differ in the expression of the value semantics. The most neutral lexeme in terms of rating semantics is face. In the second place is betlexeme, but in this lexeme the negative attitude to reality is clearly felt. For example, in the sentences Yuzingni yuv, Betingni yuv, the idea is the same, but the attitude is different: the second sentence is usually disregard for the big to the small. [Rahmatullayev Sh. Modern Uzbek literary language. -T .: University. 2006. p. 61]

In Qadiri's comedies, the author also uses the following images in the context of facial sema: [Avom o'rtasinda bo'Isun, ulamo orasinda bo'Isun ul «Domla Sharif Oxund» bo'lub tanilgan va bu ismni eshitkan, yetti yashardan yetmish yasharning ko'z oldig'a katta salla, uzun chopon, semiz tan, o'ng qo'lining yengidan to'rt ellik tasbih uchi ko'runub turg'an, qib-qizil barkash yuz, moshkichiri soqol bir zot kelib bosar edi]. There were adjectives used for definition and description like "semiz tan", "barkash yuz", "moshkichiri soqol" serves to arouse the mood.

It is in Qadiri's comic works that the names of places have been changed in order to arouse laughter and accurately depict the image of the character. [Bu zot diniy bir olim bo'luv ustig'a siyosatdan ham xabarsiz emas edi. Amrika, Girmoniya, Ongliya, Yapo'niya, 


\section{CURRENT RESEARCH JOURNAL OF PHILOLOGICAL SCIENCES}

(ISSN -2767-3758)

VOLUME 03 ISSUE 01 Pages: 73-78

SJIF IMPACT FACTOR (2021: 5. 823)

OCLC - 1242423883 METADATA IF - 6.925

\section{Crossref

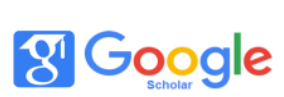

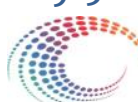

metapata

5. WorldCat fి̂ MENDELEY

Publisher: Master Journals

Faransiya, Belgiya, shuning kabi har davlatlarni yodlab bilar edi. Bunlarning hunarlarigacha ayrim-ayrim ajratar edi]. He also gave a humorous account of how the linguistic landscape of the world was reflected in the imagination of the character. [Masalan, Amrika, o'zi faranglarning bir tabaqasi, ya'ni qabilasi. Hunari: amirkon teri ishlaydir. Amirkon paxtani ham shu chiqarg'an. Girmoniya to'b to'pxona, urush aslahalarini ishlaydir. Osmon popurini ham shu kofir chiqarg'an. Ongliya - bu juda hunarmand, lokin o'zining yer yuzinda joyi yo'q. Ammo dengizga shaharlar bino qilg'an. Shuning uchun dengizlar podshosi deb aytadirlar. Farantsiya yoki Farang - bu o'zi maydachuyda ishlarga juda ham usta bir kofir; farangi igna, moshina, farangi ibi, gramafon, nag'ma va shunga o'xshash allaqancha ajoyib, g'aroyib narsalarni chiqargan. Yapo'niya - o'rusdan Po'rtortirni olg'an... Ana bunlar endi chet qironlar to'g'risida bilgan siyosati. O'zimizning yaqin qironlardan, masalan, Xitoy, Turkiya, Buxorolar haqqinda yetti yoshliq vaqtindan beri ma'lumoti bor. Xitoy — hunari xitoy qog'oz, ipak jujum, jonon piyola... nufusi juda ham ko'b, na hisobda, na kitobda bor]. It is also clear from this description that Abdullah Qadiri uses special lexical riches of our language in his humorous works. It is obvious that the author uses more figurative expressions in his comic works: [Samarkentni olmoqg'a qo'shun tortg'anda yo'l ustida daryoyi Nilmi, Jayhunmi degan bir daryog'a to'g'ri kelar ekan. Daryoni ko'pruksiz ko'rganda ijrg'amig'a kelturmay cherigini suvg'a bosib odamdan ko'pruk qilib o'tub ketar ekan. Mana, ko'bligi shuncha ekan!! Turkiya yer yuzining sultoni, ahli kuffordan boj xiroj oladir]. It is also clear from this passage that in addition to figurative expressions, Qadiri also used eloquence and rhetoric effectively. In particular, the reader knows that the phrase, “Daryoni ko'pruksiz ko'rganda ijrg'amig'a kelturmay cherigini suvg'a bosib odamdan ko'pruk qilib o'tub ketar ekan" is in any case far from the truth. In order to increase its effectiveness, the following phrase was used: [Qahru -g'azabidan zaminu-zamon, makinu makon titraydir]

Abdullah Qadiri has unique analogies that make the reader feel funny and powerful. [“Ovozi tojik"ning tilagicha adovatimiz manashu ikki yo'sin tabiiy ravishda ho'kizning shoxidek o'sib chiqqandir]. (P. 704)

The author's article "Past and Now" No. 24 of 1926 "Mushtum" also confirms that he was a master of comedy. The use of humorous lexemes from the first sentence of the text of the article indicates the author's intention. [Har bir zamonning o'z oldig'a och devonaлари, dambalsiz sharmadalari bo'lg'anidek, ikkinchi tomonda shahzoda va kiromandalari ham bo'ladir.] Bizning hozirgi kunimizda aksar misolni o'z kasbimizdan olsaq muxbirlar borki, bir-ikki so'm oladirg'an gonorari (qalam haqqisi) uchun ertadan kechkacha idoradan idoraga, chuqurdan chuqurga tushib, itdek horib, o'sha peshona terisi bo'lg'an uch yarim paqirni ham janjal va ovoragarchiliksiz ololmaydir. Yozg'uchilarimiz borki, ertayu kech matbaalarning taq-tuqi, qo'rg'oshinlarning zahri, baxtsizlikning qahri ostida ishlab, kezi kelganda non, deb kesak tishlaydirlar va idoralar marhamatidan har o'n besh kunda bellariga tugib berilgan besh-o'n tangani ham ko'pincha uyga yetkuncha yo'lda tushurib qo'yadirlar. Odamlar borki, mo'ylabini burab, qornini silab, huzur va halovat deganingni ikki yamlab bir yutqani holda yana oyig'a faloncha chervonni beliga tuflab tugadir.

"The lexical meaning of a given stage of language development is called modern lexical meaning. For example, the meanings of the eye-lexeme described above are modern lexical meanings in Uzbek. 


\section{CURRENT RESEARCH JOURNAL OF PHILOLOGICAL SCIENCES}

(ISSN -2767-3758)

VOLUME 03 ISSUE 01 Pages: 73-78

SJIF IMPACT FACTOR (2021: 5. 823)

OCLC - 1242423883 METADATA IF - 6.925

Modern lexical meanings are classified from a number of points of view: primary meaning and derivative meaning, literal and figurative meaning, nominative meaning, and figurative meaning. One of these classifications does not exclude the other, but reflects a different approach to the same event. The above types of lexical meaning are determined on the basis of polysemous lexemes." [Rahmatullayev Sh. Modern Uzbek literary language. -T .: University. 2006. p. 64]

The attitude of what we have written here depends on the fact that our friend from Namangan "Giq" sent to our office a piece of the whole poem written by the deceased Abdurazzoq crazy, one of the poets of the last century, said "I just copied it from real one" asking the prince of his century to click it on his journal. We read the whole thing and the tragedy of our grandfather's insane death came to mind.

[Mehnatkash yelkasida kun ko'rguchi "baxtlilar" shoirning muhtojligidan isti'foda qilib, uning talantini o'z kayflariga, ermakla-riga qurol qilg'anlar va o'zini “devona”lar qatorig'a kiritkanlar]. The lexemes highlighted create a satirical meaning in contrast to the content of the text, the speech situation.

It is worth noting that the following text is completely satirical, in which the use of prose rhyme, prostration, which is found in epics of folklore. [Ularning arzimag'an in'omlari va ehsonlari uchun ko'ringiz bechora bobo nimalarni yozadir: "Sayyidim, tojisarim, nuktarasim, axdi qadim bandaga bir salla karam qilg'an edilar, magaram xotiri ashraflaridan mahv o'lub ketkan uchun yodi muborakka solay, deb bahri tavil ayladim insho: Malikai dodi raso, muhtashamo, onglaki, kallamdagi sallam titilib qiymayu parcha qiyilib, ilma uloq, laxlaxu ravzan, ko'zaning teshigi, ugra yuvuq, burda chuviq, ko'hna kafandek chirigan, eski yamoq solg'ali bo'lmas, yaramas ham suzuk, afsurda tugun, zo'rg'a turgan, kuya urgan, chirigi xo'rda nadomat, ipi chandima chiltari gadodek o'ralib, balki yuzuboshimg'a tushib, sufra-sochug'dek osilib, bu erta-yu kech bodi sabo qiladir]. In this example, metaphor and metonemia are also actively used. In particular, several examples of metaphors are expressed through unique analogies.

The word Devona means mad, merchant, wanderer, lover, madman, depending on the context of the speech. In the following sentences, devona is expressed in both literal and figurative senses: [Shahzodaning eski sallasini so'rab bahri tavil insho qilgan Abdurazzoq devonaning holi bilan bu kungi "devonalarimiz" orasida bo'lsa ozg'ina farq bordir. UI ham Sho'rolar hukumatining keyingi "devonalar" turmishini tuzatish niyatidaligi].

In comics, analogies are actively used, as well as metaphors and metonemes. Prose creates a humorous image from lexemes in the form of rhymes. This table can be expressed as follows:

\section{Table 1.2.2}


CURRENT RESEARCH JOURNAL OF PHILOLOGICAL SCIENCES

(ISSN -2767-3758)

VOLUME 03 ISSUE 01 Pages: 73-78

SJIF IMPACT FACTOR (2021: 5. 823)

OCLC - 1242423883 METADATA IF - 6.925

\begin{tabular}{|c|c|c|}
\hline & Analogies & $\begin{array}{c}\text { Examples of } \\
\text { saj based on humor } \\
\text { in prose }\end{array}$ \\
\hline & Sayyidim & ilma uloq \\
\hline & Tojisarim & ugra yuvuq \\
\hline & Malikaidodi raso & zo'rg'a turgan \\
\hline & muhtashamo & kuya urgan \\
\hline & ko'hna kafandek & mo'ylabini burab \\
\hline & sufra-sochug'dek & qornini silab \\
\hline
\end{tabular}

At the same time, it is necessary to comment on A. Qadiri's thoughts on comedy. According to the author, there are two types of criticism in the world of literature; serious criticism and humorous criticism. Serious criticism, while making changes to its target, is often more ambiguous. It can be said that serious criticism is specific to the people in question, that is, to the upper class, the intelligentsia. After that, serious criticism cannot be reduced to going into every corner of life. Although viewed in this respect, it is far from a mass feature.

According to Qadiri, “... comedy, the second type of criticism (in the sense of satire), can be called popular. Because laughter is a critique of life and a flying eagle. Weakness, jealousy, hatred, greed, and so on, which are not suitable for living conditions, feed him. Humorous criticism is close to the soul of the common man and translates to the issues he feels but cannot express.

\section{CONCLUSION}

Although our comedy has a long history, our new comedy has not yet found its true foundation. After all, the impulse of the October Social Revolution put us to sleep on the streets of the Renaissance. From our mother we started working in various fields. Therefore, we do not see tension in today's comedy, and our comedy complexes such as "Mashrab" and "Mushtum" cannot go deeper in comedy. However, I must say that they are the pioneers of this principle and the instigators of future comedians." In general, the author's description of comedy and its types complements other similar descriptions. 
CURRENT RESEARCH JOURNAL OF PHILOLOGICAL SCIENCES

(ISSN -2767-3758)

VOLUME 03 ISSUE 01 Pages: 73-78

SJIF IMPACT FACTOR (2021: 5.823 )

OCLC - 1242423883 METADATA IF - 6.925

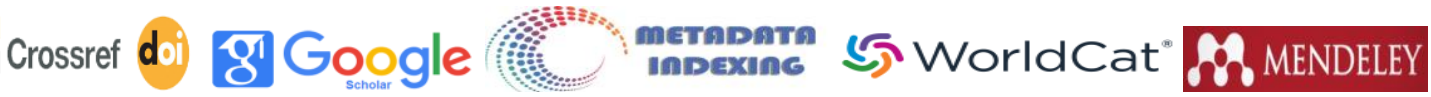

Publisher: Master Journals

In his works, Abdullah Qadiri used Uzbek words and suffixes that not available in Uzbek dictionary contents, but can be actively used today. Especially in comics, Uzbek words are relatively common. Here, too, the writer uses idioms when necessary to describe the character of the character. There is also a need to study the idioms used in his comics.

\section{REFERENCES}

1. Rahmatullayev Sh. Modern Uzbek literary language. -T .: University. 2006. 61-b.

2. Rahmatullayev Sh. Modern Uzbek literary language. -T .: University. 2006. 64-p.

3. Davlatova R.H. Signal units in the text. // Journal of Uzbek Language and Literature. B.100-104 .

4. Lutfullaeva, D. (2021). Linguistic Principles of Naming Trade Objects in Uzbek Language. Psychology and Education Journal, 58(1), 10271032.

5. Davlatova, R. H. STUDIES FUNC STUDIES FUNCTIONAL-SEMANTIC FIELD OF DEI TIC FIELD OF DEIXIS IN THE XIS IN THE UZBEK LANGUAGE. Scientific Bulletin of Namangan State University, 2(3), 77.

6. Orifjonova, G. R. (2018). ETHNOGRAPHIC COLLECTIONS OF THE STATE MUSEUM OF TEMURIDS'HISTORY: SAMPLES OF ART OF COPPER-EMBOSSING. ISJ Theoretical \& Applied Science, 4(60), 309-312. 